\author{
MONIKA JAKUBEK-RACZKOWSKA \\ UNIWERSYTET MIKOŁAJA KOPERNIKA W TORUNIU \\ JULIUSZ RACZKOWSKI \\ UNIWERSYTET MIKOŁAJA KOPERNIKA W TORUNIU
}

\title{
NIEROZPOZNANY GRADUAŁ Z KOŚCIOŁA ŚWIĘTOJAŃSKIEGO W TORUNIU - PRZYCZYNEK DO BADAŃ NAD KSIĘGAMI MUZYCZNYMI DIECEZJI CHEŁMIŃSKIEJ W ŚREDNIOWIECZU*
}

$W^{\prime}$ zbiorach Muzeum Diecezjalnego w Toruniu od 20I4 r. znajduje się dużych rozmiarów liturgiczny kodeks muzyczny pochodzący z archiwum dawnego kościoła parafialnego, obecnej katedry św. Jana Chrzciciela iśw. Jana Ewangelisty w Toruniu (il. I). Nie jest on kompletny (z całą pewnością brakuje ostatnich kart, na co wskazuje niepełny tekst ostatniej zachowanej sekwencji), ponadto kilka kart wycięto w bliżej nieokreślonym czasie ${ }^{2}$; nie posiada ani eksplicitu, ani kolofonu, co utrudnia jego rozpoznanie. Dzieło to zostało wprowadzone do literatury w 1933 r. przez Gwidona Chmarzyńskiego ${ }^{3}$

* Tekst referuje wstępne wyniki badań i prac inwentaryzacyjnych, wykonywanych w ramach projektu $\mathrm{NPRH}$ nr oI22/NPRH6/HiI/85/20I8, Inwentarz Sztuki Torunia, cz. I, Dziedzictwo sakralne, zespót staromiejski. Przedstawione tu obserwacje są efektem pierwszej fazy podjętych niedawno studiów nad tym obiektem, możliwych dzięki życzliwości dyrekcji Muzeum Diecezjalnego w Toruniu (dalej cyt. MDT). Za udostępnienie zabytku i pomoc w jego dokumentacji składamy w tym miejscu podziękowania p. Katarzynie Bucław z Działu Edukacji i Dokumentacji Muzealnej MDT.

I $\mathrm{Nr}$ inw. MDT-K-oo3, księga na pergaminie, I7I kart, I9 składek (kwinterniony), wym. kart: ok. 58 x $39 \mathrm{~cm}$ (wielkość poszczególnych kart nieznacznie się różni); w oprawie drewnianej o skórzanym obleczeniu (deski oprawy 63 x 40,3 cm; grzbiet $7 \mathrm{~cm}, 9$ zwięzów). Kodeks zachowany jest w dość dobrym stanie; jego blok, choć obecnie słabo zespolony z oprawą, nie jest naruszony; nosi jednak ślady długotrwałego użytkowania (w tym zabrudzenia i zmiany mikrobiologiczne w dolnych narożach kart), w wielu miejscach czytelne jest pudrowanie inkaustu (np. k. IO7r), a interwencji konserwatorskiej wymagałyby w pierwszej kolejności karty ochronne i najgorzej zachowana karta incipitowa ze śladami licznych reparatur, pozbawiona zewnętrznego marginesu, $\mathrm{z}$ dosztukowanymi partiami bocznymi.

2 Karty: Is (początek liturgii Bożego Narodzenia), IOI (początek liturgii wielkanocnej), I22 (początek liturgii Zielonych Świąt). Karty zostały wycięte najprawdopodobniej z uwagi na walory artystyczne; przy introitach najważniejszych świąt należałoby się spodziewać wybujałej dekoracji (być może - miniatur). W bliżej nieokreślonym czasie z wielu kart wycięto też inicjały (3v, 56r, 57v, 6rv, 66v, 73r, 76r, II8v, I23r, I28r, I32v, I37v).

3 Gwido Chmarzyński, „Sztuka w Toruniu”, w: Dzieje Torunia. Praca zbiorowa z okazji 70o-lecia miasta, red. Kazimierz Tymieniecki, Toruń 1933, s. 517-518; badacz zwrócił uwagę jedynie na pierwszą kartę antyfonarza z inicjałem „A” oraz listwami roślinnymi, dekorowanymi „ptactwem, niedźwiedziem i małpkami", datował ok. I50o. 
i Zygmunta Mocarskiego ${ }^{4}$ jako antyfonarz, datowany około I5Oo r., a należący do pierwotnego zasobu biblioteki świętojańskiej i wykonany w Toruniu. Z przesunięciem datowania wstecz, na 3. ćwierć XV w., kodeks - określany jako dzieło skryptorium toruńskiego - przywołany został później kolejno: w studium Alicji Karłowskiej-Kamzowej poświęconym miniatorstwu na Pomorzu Wschodnim5, w katalogu wystawy czasowej Ars Sacra ${ }^{6}$ (Toruń, 993 r.) oraz w katalogu Malarstwa gotyckiego w Polsce 7 . Obecność w literaturze zapewniła dziełu gwaszowa dekoracja karty Ir, która jako jedyna przykuwała uwagę badaczy; mniej wnikliwie traktowano dekorację kaligraficzną. Kodeks nie doczekał się natomiast pełnego rozpoznania ani od strony struktury materialnej, ani zawartości (brak analizy treści zaowocował utrwaleniem się błędnego rozpoznania typu księgi), ani paleografii; rewizji wymaga zaproponowane w literaturze datowanie oraz przyjmowana bezkrytycznie proweniencja ze średniowiecznego zasobu librarii parafialnej. Księga zasługuje też na uważne studium zabytkoznawcze i kodykologiczne na tle zachowanej spuścizny rękopiśmiennej państwa krzyżackiego. Niniejszy komunikat, zawierający wstępne rozpoznanie dzieła ${ }^{8}-$ zwłaszcza w kontekście jego warsztatowych, artystycznych powiązań - jest preludium do dalszych badań nad większą grupą piętnastowiecznych muzycznych ksiąg liturgicznych z państwa krzyżackiego w Prusach.

\section{ROZPOZNANIE ŹRÓDŁOZNAWCZE I KODYKOLOGICZNE}

Wbrew dotychczasowej literaturze, księga toruńska nie jest antyfonarzem, lecz graduałem (i tak została opisana na ekspozycji w MDT). Z racji utrwalonego błędnego rozpoznania, zabytek nie został uwzględniony w badaniach ks. prof. Jerzego

4 Zygmunt Mocarski, „Książka w Toruniu”, w: Dzieje Torunia, op. cit., s. 355. Mocarski (Ksiażka w Toruniu do 1793. Zarys dziejów, Toruń 1934, s. I3), określił kodeks jako antyfonarz z pierwszych lat XVI wieku.

5 Alicja Karłowska-Kamzowa, „Malarstwo miniaturowe”, w: Jerzy Domasłowski, Alicja KarłowskaKamzowa, Adam S. Labuda, Malarstwo gotyckie na Pomorzu Wschodnim, Warszawa-Poznań 1990 (= Prace Komisji Historii Sztuki I7), s. 213-2I4, il. II7; badaczka uznała kodeks za jedyną pozostałość ksiąg chórowych z bogatych kościołów toruńskich, omówiła krótko zdobienia karty Ir i zaznaczyła istnienie dekoracji filigranowej, którą wpisała w lokalną tradycję artystyczną.

6 Stanisław Cierkowski, „Antyfonarz”, w: Ars sacra. Dawna sztuka diecezji chetmińskiej, red. Michał Woźniak, Toruń 1993, s. 55, nr kat. 5I; badacz zidentyfikował kodeks jako dzieło pracowni wschodniopomorskiej, związane z diecezjalnym chorałem gregoriańskim, wykorzystywane przez scholę parafialną, przeoprawione w I693 r. przez Jacoba Derlickiego.

7 Anna Palińska, „Antiphonarium”, w: Malarstwo gotyckie w Polsce, t. 2, Katalog, red. Adam S. Labuda, Krystyna Secomska, Warszawa 2004, s. 400; hasło zawiera identyfikację kodeksu jako Antipohnarium de tempore, opis dekoracji karty Ir oraz krótkie omówienie dekoracji kaligraficznej (filigran pączkowy).

8 Przeprowadzone przez nas dotąd prace objęły pełną dokumentację pomiarową i fotograficzną, analizę wizualną oraz badania nieniszczące pigmentów i inkaustu z użyciem przenośnego spektrometru rentgenowskiego XRF. Przyniosły one ogólne rozpoznanie źródłoznawcze i zabytkoznawcze. Dalszych pogłębionych studiów wymagają kwestie historyczno-artystyczne i tegumentologiczne; na specjalistyczną analizę czekają paleografia (w tym notacja) i aspekty muzykologiczne. 
Pikulika nad średniowiecznymi graduałami w księgozbiorach polskich9 i dla badaczy ksiąg muzycznych (zwłaszcza zasobów pochodzących z terenów dawnego państwa zakonnego) stanowi nowy, nieznany dotąd materiał poznawczy. Zawartość księgi ogranicza się do Proprium de tempore (II8 oficjów od pierwszej niedzieli adwentu do 23. niedzieli zwykłej), dalej następują formularze mszalne In dedicatione Ecclesiae (I53r) oraz In dedicatione altaris (I54v) i formularze mszy wotywnych: Contra pestilentiam (I55r) i Pro defunctis (I56r). Każde z oficjów zawiera zmienne śpiewy mszalne: introit, graduał, śpiewy allelujatyczne i/lub trakt oraz psalmy, śpiew offertorium i communio. Księgę kończy ordinarium missae (I6ov-I70v) z parami śpiewów stałych Kyrie (8) - Gloria (8) i Sanctus (4) - Agnus (4), a także niepełne prosarium, w tym dwie sekwencje na Boże Narodzenie: Grates nunc omnes redamus Dominus Deo (I7Ir-v) i Eia recolamus laudibus piis digna (I7Iv) oraz sekwencja Benedicta semper sancta sit Trinitas [...] (I7Iv) na święto Trójcy Świętej. Z tej ostatniej przetrwał tylko początek, kończy się ona na słowach „pater dominus filius”.

Liturgia toruńskiego graduału ma liczne cechy zwyczaju dominikańskiego, zwłaszcza w zasobie wersetów allelujatycznych ${ }^{10}$ (często zbieżnych także z tradycją cysterska), ale nosi też piętno liturgii niezakonnej, diecezjalnej, m.in. w formularzach In dedicatione ecclesiae ${ }^{\mathrm{II}}$ lub mszy za zmarłych $^{\mathrm{I2}}$. Jest to typowe dla uzusu krzyżackiego $^{13}$ i potwierdza powstanie oraz użytkowanie księgi na terenach państwa zakonnego ${ }^{\text {I4; }}$ zawartość kodeksu wymaga pod tym kątem dalszych szczegółowych badań.

9 Zob. m.in.: Jerzy Pikulik, „Indeks śpiewów ordinarium missae w graduałach polskich do I60o”, w: Muzyka religijna $w$ Polsce. Materiaty $i$ studia, t. 2, red. Jerzy Pikulik, Warszawa 1978, s. 139-272; tegoż, Śpiewy Alleluia o Najświętszej Maryi Pannie w polskich graduatach przedtrydenckich, Warszawa 1984 (= Muzyka religijna w Polsce. Materiały i studia 6); tegoż, Polskie graduaty średniowieczne, Warszawa $200 \mathrm{.}$

Io Do odrębności dominikańskich należą m.in. wersety allelujatyczne oktawy Pentecosten (I24r-I27v) oraz niektóre wersety allelujatyczne i graduały niedziel zwykłych: VI (I35r-v), VIII (I37r), IX (I38r), XIV (I42r), XV (I42V), XVI (I43v), XVII (I54r), XVIII (I47r), XIX (I48r), XX (I48r), XXI (I49v), XXII (I5Ir), XXIII (I52v). Badania porównawcze oparto na zestawieniach opracowanych przez Jerzego Pikulika (Polskie graduaty, op. cit., passim).

II Graduał MDT-K-003 zawiera werset allelujatyczny liturgii diecezjalnej Vox exultationis (I53v), a formularze zakonne - werset Adorabo ad templum, zob.: J. Pikulik, „Polskie Graduały”, op. cit., s. 170-17I.

I2 Formularz w MDT-K-o03 nie odpowiada stałym formularzom zakonnym (zob. ibid., s. 174-I75), stanowi raczej połączenie dwóch formularzy, stosowanych w liturgii diecezjalnej (por. ibid., s. 172-173).

I3 Zakon krzyżacki w poł. XIII w. przyjął liturgię dominikańską, ale nadał jej pewne cechy odrębne; Notula Dominorum Teutonicorium została zatwierdzona przez papieża Aleksandra VI. O zwyczaju liturgicznym Zakonu NMP zob. m.in.: Paweł Gancarczyk, „Kultura muzyczna zakonu krzyżackiego w Prusach”, w: Fundacje artystyczne na terenie państwa zakonnego w Prusach, red. Barbara Pospieszna, t. 2, Eseje, Malbork 20IO, s. 269-282, zwłaszcza s. 269-273; Waldemar Rozynkowski, „O liturgii w zakonie krzyżackim w średniowieczu”, w: Rewitalizacja kościota Najświętszej Marii Panny w Malborku, red. Janusz Hochleitner, Malbork 20I6, s. 49-66, zwłaszcza s. 49-50.

I4 $\mathrm{Na}$ terenie diecezji pruskich używano krzyżackich ksiąg liturgicznych, zob. szczegółowo: Waldemar Rozynkowski, „Krzyżackie księgi liturgiczne w parafiach diecezji chełmińskiej, pomezańskiej, warmińskiej oraz włocławskiej po I466", w: Kościót w Polsce, dzieje i kultura, t. 4, red. Jan Walkusz, Lublin 2005, s. 237-246. 
Podłoże pisarskie księgi jest dość dobrej jakości - pergamin został dobrze wyszlifowany i nosi bardzo nieliczne naturalne wybrakowania (niewielkie otwory włosowe, naturalne ubytki dolnych narożników). Ingerencje w ten pergamin - jak drobne cery - też są bardzo rzadkie, co przy dość dużym formacie kart jest warte odnotowania. Zachowały się ślady przygotowania kart pod zapis - gdzieniegdzie czytelne są pozostałości wytartego później liniowania. Brzegi kart noszą nieliczne otwory w odstępach co 3,5 cm, odpowiadające liniom systemów muzycznych. Dzieło jest opatrzone wyłącznie pierwotną foliacją, która wprowadzona została czarnym inkaustem u dołu strony verso i doprowadzona do karty I54 (ostatnie siedemnaście kart księgi nie ma foliacji).

Schemat graficzny karty (il. 2), wykreślony czerwonym tuszem, tworzy dziesięć czteroliniowych systemów na stronie (lustro: $45 \times 27 \mathrm{~cm}$ ). Zapisy oficjów i rombowa notacja naniesione zostały czarnym inkaustem ${ }^{15}$, pismem jednej ręki. Wersety spisane są regularną teksturą, bez łańcuszków międzysylabowych czy międzysłownych. Rubrykowania, wykonane inkaustem barwionym cynobrem (pigmentem na bazie siarczku rtęci) ${ }^{16}$, są w kodeksie nieliczne: użyto ich do oznaczenia świąt, najczęściej w abrewiacjach, rzadziej w kilkuwersowym zapisie pełnym (przy czym nie wszystkie święta zostały oznaczone słownie, niektóre zaznaczono tylko pionowymi znacznikami przy introicie $\left.{ }^{17}\right)$. Rubrą oznaczano też poszczególne śpiewy ${ }^{\mathrm{I} 8}$, stosując na ogół sygle (minuskułowe lub z użyciem majuskuły): graduale (gra, znacznie częściej: $G \cdot \operatorname{lub} g^{\cdot}$ ), tractus (Trct, tract, tractus), offertorium (Off, offlub of, bardzo rzadko offer), communio ( $c \bar{o}$, bardzo rzadko com), a także części mszy w formularzach skróconych ${ }^{19}$; rubrykator stosował też przekreślenie pierwszych liter w tekście.

Poza kartą pierwszą, w kodeksie występują dwa typy inicjałów o tym samym formacie (na wysokość jednego systemu i jednego wersu). Pierwszą grupę stanowią barwne, naprzemiennie czerwone i błękitne lombardy (wprowadzane bez użycia lettre d'attente). Wyróżniano nimi początki introitów, graduale, traktów, offertoriów i ko-

I5 Pomiary fluorescencji promieniowania rentgenowskiego (XRF) wykazały następujący skład pierwiastkowy inkaustu (w przybliżeniu): Cu 49\%, Fe $38 \%$, Pb 5\%, Zn I,3\%. Duży udział procentowy miedzi wskazuje, że nie jest to typowy atrament żelazowo-galusowy, ale materiał modyfikowany być może w ramach praktyki warsztatowej skryptorium, podobnie jak inkaust zastosowany w pelplińskim graduale Li3, modyfikowany cynkiem, zob.: Mirosław Wachowiak, „Nieinwazyjne badania graduału Li3 przenośnym spektrometrem XRF”, w: Pelplinski graduat LI3. Dzieto - badania - konserwacja, red. Juliusz Raczkowski, Monika Jakubek-Raczkowska, Toruń 2019 (= Studia nad skryptorium i spuścizną rękopiśmienną średniowiecza I), zwłaszcza s. I9I-I93, co wymaga dalszych badań porównawczych.

I6 Skład pierwiastkowy inkaustu: $\mathrm{Hg} 90 \%, \mathrm{Fe} 4 \%, \mathrm{Cu} 3,5 \%$.

I7 Np. k. II2v (Dominica III post Pascham), II4r (Dominica IV post Pascham), iI5r (Dominica V post Pascham), II7r (In vigilia Ascensionibus), I53r (przy święcie In dedicatione ecclesiae).

I8 Nie oznaczono wersetów allelujatycznych, które rozpoczynają się kadelami. Wyjątkowo pełnym słowem „Impnus” rubrą oznaczono hymn Benedictus es Dominus pater nostrorum, k. 9r.

I9 Np. k. 6v (Feria sexta - fragment), I8r (In octava nativitatis - cały formularz), 43r-44v (Sabbato quatuor temporum - fragmenty skrócone), 44r (Dominica II Quadragesimae - cały formularz); w zapisach skróconych sygle na ogół z wielką literą. 
munii. Dekoracja kaligraficzna (tzw. filigran pączkowy) w odwrotnej barwie ${ }^{20}$ pojawia się na ogół tylko w inicjałach introitów. Drugą grupę stanowią kaligraficzne, dekorowane ornamentalnie czarne kadele, stojące na początku wszystkich pozostałych wersetów: psalmów, versus alleluiatici i in. ${ }^{21}$. Zdobione są one filigranem w barwie litery oraz pionowymi pociągnięciami rubrą i nadają zapisowi dużej elegancji ${ }^{22}$.

Historię długotrwałego użytkowania kodeksu dokumentują licznie występujące dopiski liturgiczne różnych rąk, wprowadzone w czasach nowożytnych i jak się wydaje, jeszcze w XIX wieku. Uzupełnienia te, głównie piórem, lokalizowane są zarówno na marginesach, jak i w tekście oraz w nutownicach ${ }^{23}$. Ciekawym przykładem szacunku wobec pierwotnego zapisu jest sposób „rekonstrukcji” dolnego fragmentu karty 45, wybrakowanej w nieznanych okolicznościach: na obu stronach karty uzupełniono formularze, imitując dość chwiejnie teksturę gotycką i kaligraficzną dekorację inicjału. W kilku przypadkach dopisano brakujące formularze mszalne, uaktualniając uzus: np. msze wotywne Pro quacumque necessitate (56r) i Pro pace (I47r), święto Przemienienia Pańskiego ${ }^{24}$ (I3r) i in.; uzupełnienia tego typu, podobnie jak uzupełnienia wersetów, wpisywano na zewnętrznym marginesie ${ }^{25}$. Liczne są teksty nadpisywane drobnymi literami w obrębie wersetów ${ }^{26}$. W oryginalny zapis wprowadzano też dopiski natury pragmatycznej, np. odsyłacze do numerów kart z pełną melodią ${ }^{27}$, brakujące oznaczenia świąt i niedziel czy nazw formularza, które miały ułatwić użytkowanie księgi ${ }^{28}$ (a może i uniknięcie błędów, jak w przypadku uzupełnienia w adwentowym wersie „Ecce vir concipiet” na „Ecce virgo concipiet” na k. 6v). Gdzieniegdzie graduał został uzupełniony w późniejszym czasie o zapisy

20 Czerwień uzyskiwano na bazie cynobru, błękit - azurytu. Kilkanaście liter inicjalnych przyozdobiono filigranem w fioletowawym zabarwieniu, uzyskiwanym - jak wynika z interpretacji pomiarów składu pierwiastkowego - z mieszaniny cynobru, czerwieni żelazowej i bieli ołowiowej.

2I Wyjątek stanowią hymn Benedictus na sobotę adwentowych Suchych Dni (9r-Ior) oraz obrzędy niedzieli palmowej (77r-8Ir), gdzie wersety zdobione są inicjałami barwnymi.

22 Niemal znikają one w Ordinarium, gdzie wyróżniają wyłącznie słowo „Benedictus”.

23 Na uwagę zasługuje gęsta sieć uzupełnień np. przy święcie Bożego Narodzenia (I3r-I4r).

24 Święto Transfigurationis, ustanowione w 1456 r. a obchodzone 6 sierpnia, należy do listy Proprium de sanctis; zostało wpisane na marginesie przy oficjum Bożego Narodzenia In Gallicantu, najpewniej w XVII w. (przed przeoprawieniem kodeksu).

25 Np. k. I3r, I4r, 28v, 38v, 46r, 98r, II 4r, I28r, I35r, I43r, I48r, I5Ir-v.

26 Np. k. 39v, IO7r, IIOr, II3r, II4V, II7V, II9r, I25r, I26r, I28r, I33r-v, I34r, I37r, I4Or, I4Ir, I43V, I47V, I48r-v, I52V, I55V.

27 Są to dopiski różnych rąk, z różnego czasu, wprowadzane przy introitach i przy zapisach skróconych w tekście lub na marginesach, np. k. I3IV, I33r, I34V, I35r, I38r-v, I39r-v, I4Or, I4Ir, I42r-v, I43V, I44r, I45V, I46v, I55r. Warto zwrócić uwagę, że rubrykowane odsyłacze tego typu wstawiał także sam pisarz przy formularzach skróconych, np. k. I25v, I26r, I26v, I27v.

28 Np. k. 56v („Gra” w obrębie inicjału introitu); 73v („of” i „com” w inicjałach); 74r (oznaczenie „Feria Quinta” czarnym inkaustem w miejscu pozostawionym na rubrykę przez średniowiecznego pisarza); 76r (dopisek „Feria sexta \& Sabbato” na zewnętrznym marginesie, w tekście sygiel „Sab” czarnym inkaustem), 76v-77r (oznaczenia „Gra”, „Offt” i „com” w lub przy inicjałach); itd. 
melodyczne. Takich dopisków dokonywano na dolnych marginesach kart ${ }^{29}$. Uwage zwraca m.in. wpisany tą samą ręką na czterech kolejnych stronach k. I29v-I3Ir tractus (canticus) oficjum Bożego Ciała $\mathrm{Ab}$ ortu solis ${ }^{30}$ w czarnym systemie nutowym, powyżej i poniżej foliacji. Jako ciekawostkę można potraktować wreszcie graffiti z datą I562 w obrębie inicjału na k. $25 \mathrm{v}$.

Dowodem historycznego użytkowania księgi są działania podjęte przy jej oprawie. Jest ona dość surowa i nie ma cech jednoznacznie datujących (il. 3); w literaturze przyjmowano przeoprawienie bloku w końcu XVII w. ${ }^{3 I}$. Wskazywałoby na to wtórne przycięcie kart, ingerujące w nowożytne dopiski na marginesach (np. I3r, 56r, I35r, I43r, I47r). Skórzane obleczenie zachowało się w niezbyt dobrym stanie; z metalowych aplikacji przetrwały tylko płaskie kute listwy obrzeży z kulistymi guzkami, oraz cztery gładkie mosiężne guzy przy zewnętrznym brzegu (po innych aplikacjach, w tym medalionach centralnych, pozostały tylko ślady mocowań) oraz zaczep w kształcie lilijki z fragmentem zawiasu na awersie. $\mathrm{Na} \mathrm{k}$. 6r na zewnętrznym marginesie umieszczony został dopisek, który może łączyć się ze zmianą oprawy: „cteri karty nowe pergaminowe niepisane / na brzegach papierowych Ośm A.D. I693”. Tę samą datę nosi wpis - być może własnościowy - na przedniej karcie ochronnej, wymieniający Jakuba Derlickiego $^{32}$. Na papierowe karty ochronne w przedniej części księgi wprowadzone zostały dwa nowożytne zapisy słowno-muzyczne Credo autorstwa dwóch różnych rąk ${ }^{33}$.

\section{ANALIZA ZDOBIEŃ I WNIOSKI PROWENIENCYJNE}

Karta incipitowa Ir jest najbardziej okazała pod względem dekoracji - ozdobiona została gwaszowymi iluminacjami o zróżnicowanej, intensywnej niegdyś kolorystyce. Inicjał incipitowy „A(d te levavi)” to jedyny zachowany w księdze inicjał historyczny ${ }^{34}$. Jego wypustka marginalna, przechodząca w bordiurę wokół lustra tekstu, zbudowana jest z malowanych walorowo, wielobarwnych, strzępiastych liści, w które na bocznym

29 Przykładowe dopisane wersety z notacją muzyczną: k. 43v, werset „et faciunt iustitiam in omni tempore”, być może niedokończony; k. 44r, trakt Confitemini Domine; k. I54r przy święcie In dedicatione ecclesiae werset allelujatyczny „Adorabo ad templum sanctum et confitebor nomini tuo alleluia”; w partii Kyriale jeden zapis melodii Kyrie notacją rombową i pismem imitującym teksturę; na ostatniej zachowanej karcie kodeksu sekwencja Lauda Sion Salvatorem wraz z notacją muzyczną, zaopatrzoną w dekoracyjny, nowożytny inicjał.

30 Brzmienie całego zapisu: (I29v) „Ab ortu solis usque ad occa / sum magnum est nomen meum in gen (Izor) tibus. Et in omni loco sacrifi: / catur et offertur [nomini meo] oblatio (I3Ov) munda quia magnu[m] est nomen meum in gen (I3Ir) tibus. Venite comedite panem meum et bi: / bite vinum quod miscui vobis".

3I S. Cierkowski, op. cit., s. 55; A. Palińska, op. cit., s. 400.

32 Identyfikacja tej postaci wymaga dalszych badań źródłowych; Cierkowski (op. cit., s. 55), identyfikował tu nazwisko introligatora.

33 Palińska (op. cit., s. 400), datowała te dopiski na wiek XVII.

34 Nie można wykluczyć, że bogatsze dekoracje towarzyszyły introitom najważniejszych świąt, których karty wycięto, por. przyp. 2. 
marginesie wplecione są realistycznie malowane ptaki, u dołu zaś pojawia się postać niedźwiadka i - częściowo zaklejona pergaminem w wyniku wtórnych, nowożytnych reparatur (por. il. I, dół karty) - postać małpki; na lewym marginesie we floraturę wpleciono antropomorficzna maskę (słabo widoczną spod wtórnego przeklejenia). Miniatura inicjału (il. 4) ukazuje św. Grzegorza Wielkiego - zapewne w nawiązaniu do legendarnego autorstwa chorału gregoriańskiego. Święty tronuje ze stylusem w ręce, zwrócony en trois quarts do widza, przy wysokim architektonicznym pulpicie, na którym spoczywa otwarta księga; odziany jest w obficie sfałdowaną kardynalską mantelettę. Potrójna tiara (atrybut indywidualny) wieńczy pulpit. Trzon litery inicjalnej najprawdopodobniej zdobiony był monochromatyczną floraturą, na błękitne tło rzucone są natomiast drobne gałązki malowane złotem. Motywy te wykonane są wprawną ręką, cechują się świeżością i dość wysokim poziomem artystycznym.

W dotychczasowej literaturze wskazywano na związek dekoracji kodeksu z tradycją wschodniopomorską i występowanie zbliżonych zdobień w piętnastowiecznych kodeksach zachowanych w Gdańsku35. Bezpośrednie źródło tego systemu dekoracji biło w Pradze $e^{36}$, w iluminatorstwie kręgu luksemburskiego z przełomu XIV i XV wieku. Dostarczyło ono najpewniej pierwowzorów zarówno dla typu luźno skręconej barwnej wici o strzępiastych listkach, jak i dla motywów, które w nią wpleciono ${ }^{37}$, a także dla struktury inicjału ujętego w malowaną perspektywicznie ramkę, z pastelowym trzonem litery wypełnionym wicią roślinną w tej samej barwie, z drobnymi sprężystymi odrostami i złotymi lub srebrnymi gałązkami w tle ${ }^{38}$. W muzycznych księgach czeskich początku XV w. można ponadto znaleźć ogólne analogie dla systemu i kompozycji kart, z zapisem w czerwonych nutownicach, z wykorzystaniem

35 O rękopisach „miejskich”, w posiadaniu biblioteki kościoła NMP w Gdańsku: Iwona Błaszczyk, „Iluminacje średniowiecznych rękopisów ze zbiorów pomorskich”, Gdańskie Studia Muzealne 3 (I98I), s. I07-I25, zob. zwłaszcza s. IO8-III; A. Karłowska-Kamzowa, op. cit., s. 2II-2I3; o zdobionych w podobnej konwencji rękopisach gdańskich franciszkanów zob.: Agata Larczyńska, „Piękno średniowiecznych manuskryptów. Biblioteka gdańskiego klasztoru franciszkanów na nowo odkryta”, Studia Zamkowe 4 (2OI2), s. III-I27.

36 W odniesieniu do kodeksów z zasobów mariackich w Gdańsku Błaszczyk wysnuła wręcz hipotezę, że zdobił je wędrowny malarz z Pragi, zob.: I. Błaszczyk, op. cit., s. Io9. Bardzo bliskich analogii dla systemu zdobień gwaszowych w toruńskiej księdze dostarcza np. Missale secundum notulam dominorum Teutonicorum z kościoła NMP w Gdańsku z ok. I430-40 r. (PAN BG, sygn. Ms Mar F 332), zob.: Iwona Błaszczyk, w: Malarstwo gotyckie, op. cit., s. 318-319.

37 Podobny układ i dobór motywów znajdujemy np. na bifolium antyfonarza z ok. I405 r., spisanego w Pradze, przechowanym w Metropolitan Museum of Art w Nowym Jorku, nr inw. 2013.38. W bordiurę na prawym marginesie wpleciono tam kilka barwnych ptaków, a w bordiurze bas-de-page pojawia się niedźwiadek, zob. il.: https://www.metmuseum.org/art/collection/search/4797I2?searchField=All\&amp ;sortBy=Relevance\&amp; when=A.D.+I400-I6oo\&amp; where=Czech+Republic\&amp;what=Manuscrip ts\&amp;ao=on\&amp; ft=*\&amp;offset=o\&amp;rpp=9o\&amp;pos=I, dostęp 2 I 2020.

38 Por. np. inicjały w praskich kodeksach z ok. I400 r. w Biblioteca Nacional d'Espagna, Tractatus de ludo scacorum i Dragmaticon philosophiae, zob. il.: http://bdh-rd.bne.es/viewer.vm?id=000008506I\&page=I oraz http://bdh-rd.bne.es/viewer.vm?id=0000042I93, dostęp 2 I 2020. 
barwnych lombard i dekoracyjnych kadeli ${ }^{39}$. Nie tylko zdobienia pierwszej karty, ale i ogólny charakter graficzny toruńskiego kodeksu jest zatem bardzo bliski czeskim pierwowzorom z końca XIV i z I. ćwierci XV stulecia. Biorąc pod uwagę cechy stylowe przedstawienia św. Grzegorza - przede wszystkim lekko łamiące się draperie - można przyjąć datowanie kodeksu na 2. ćwierć XV w., podobnie jak kodeksów z zasobów gdańskich.

W dekoracji kaligraficznej graduału zwraca z kolei uwagę precyzja i wielka swoboda wykonania kadel, kreślonych przez pisarza i zapewne przez niego przyozdabianych rubrą oraz wybujałość i oryginalność filigranu pączkowego inicjałów barwnych. Choć sięgają one do utartych schematów i powszechnego repertuaru ornamentyki filigranowej, nagromadzenie niektórych form i ich wzajemna relacja zdradzają jednak pewien rys indywidualizmu. Otuliny liter dekorator budował z wielokrotnych listew i szeregów pereł, chętnie stosując podwójny lub potrójny układ ciasno zwiniętej spirali z budowanymi stożkowato układami kresek. Charakterystycznym rozwiązaniem w otulinie są też fryzy z gąsienic, dające efekt falistej obwódki, od której odchodzą drobne sprężyny. W światłach liter powtarza się układ regularnych, sztywnych kłosów z pączków: rodzaj pionowych i poziomych listew, wypełniających pole sztywno i geometrycznie, lub miękko i krzywoliniowo. Innym powracającym wypełnieniem są medaliony, budowane z pojedynczych taśm i zdobione motywem spirali z pereł, pączkowego kłosa, serc, baldacha. Zdają się one sięgać do starego, lokalnego repertuaru zdobień obecnych w pruskich skryptoriach od I. ćwierci XIV w. ${ }^{40}$, ale nacechowane są rysem indywidualnym.

Tym bardziej zatem przykuwa uwagę, że dokładnie ten sam typ zdobień filigranowych znajdujemy w kodeksie muzycznym Graduale de sanctis, przechowywanym w zbiorach Biblioteki Diecezjalnej w Pelplinie pod sygn. L2 ${ }^{41}$. Został on spisany w takim samym układzie graficznym, jak MDT-K-003 (il. 5), na kartach analogicznie przygotowanych pod zapis i o bardzo podobnych wymiarach ${ }^{42}$. Kompozycja strony jest

39 Np. w przywołanym wyżej antyfonarzu, którego fragment znajduje się w Nowym Jorku, por. przyp. 37.

40 Zob. m.in. analizę zdobień kodeksów krzyżackich z I. ćwierci XIV w.: Monika Jakubek-Raczkowska, Marta Czyżak, „Wokół Biblii Lutera z Brunszwiku. Dekoracje filigranowe grupy kodeksów pruskich z XIV wieku”, w: Studia nad malarstwem gotyckim w Polsce, red. Marek Walczak, Wojciech Walanus, Kraków 2016, s. 289-306. Por. też uwagi o zdobieniach czternastowiecznych ksiąg cystersów pelplińskich: Mateusz F. Marszałkowski, „Rozpoznanie grupy rękopisów ze zbiorów Biblioteki Diecezjalnej w Pelplinie w świetle najnowszych badań”, w: Claritas et consonantia. Funkcje, formy $i$ znaczenia w sztuce średniowiecza. Księga poświęcona pamięci prof. Kingi Szczepkowskiej-Naliwajek $w$ dziesiąta rocznicę śmierci, red. Monika Jakubek-Raczkowska, Juliusz Raczkowski, Toruń-Warszawa 2017, s. 373-388, zwłaszcza s. 376-380.

4I Zob. m.in.: Kasjana Radzka, „Analiza źródłoznawcza rękopisu muzycznego ms. L2 z Biblioteki Seminarium Duchownego w Pelplinie”, w: Muzyka religijna w Polsce. Materiaty i studia, t. 3, red. Jerzy Pikulik, Warszawa I979, s. 65-I09. Za zwrócenie nam uwagi na to dzieło w kontekście analogii artystycznych dziękujemy Mateuszowi F. Marszałkowskiemu.

42 Por. Pelplin, sygn. L2, wym. karty: ok. 57 x 38 cm, lustro tekstu: 43,5 x 26; MDT-K-oo3, wym. karty: ok. 58 × $39 \mathrm{~cm}$, lustro tekstu: $45 \times 27 \mathrm{~cm}$. 
taka sama (dziesięć systemów w czerwonej czteroliniowej nutownicy), pismo też wydaje się bardzo zbliżone, choć o jego tożsamości trudno na razie wyrokować; na dalsze badania technologiczne czeka skład wykorzystanych w L2 inkaustów. Tożsame są za to bez wątpienia dekoracje kaligraficzne. W graduale pelplińskim występują licznie czarne kadele i inicjały filigranowe, w których częściej niż w egzemplarzu toruńskim stosowano charakterystyczny inkaust o fioletowo-różowym zabarwieniu. Ornamentyka inicjałów wykazuje dokładnie te same cechy charakterystyczne (w tym powtarzające się w otulinach dynamiczne układy spiral z fibrylami oraz gęste wypełnienia układami drobnych pączkowych kłosów), a nawet zbieżności w sposobie prowadzenia linii (por. il. 6-7). Można postawić ostrożną - choć posadowioną na solidnym fundamencie porównawczym - hipotezę o tożsamości warsztatowej obu ksiąg. W konsekwencji należałoby zatem przesunąć proponowane swego czasu przez s. Kasjanę Radzką datowanie pelplińskiego graduału L2 wstecz, z końca XV w. do jego pierwszej połowy.

Badania Radzkiej wykazały, że kodeks L2 zdradza powiązania z tradycją dominikańską (podobnie jak księga toruńska), przy czym repertuar śpiewów jest diecezjalny, choć względem liturgii diecezjalnej jego zawartość też wykazuje odrębności. Opierając się na analizie wewnętrznej dzieła, badaczka wskazała na prawdopodobny uzus tego kodeksu w kręgu kapituły chełmińskiej³. Jest to trop, którym powinny podążý dalsze analizy zawartości liturgicznej graduału MDT-K-ooz. Prawdopodobieństwo jego stałego użytkowania i aktualizowania w kościele świętojańskim w Toruniu nie jest wysokie: świątynia ta w okresie nowożytnym przeszła najpierw w ręce protestantów, a potem jezuitów, by w XIX w. powrócić do funkcji parafialnej. Czy przez ten czas można zakładać stałą aktualizację śpiewów gregoriańskich, której liczne dowody znajdujemy na kartach omawianej księgi? Wydaje się to wątpliwe. Zwraca natomiast uwagę, że nie tylko dekoracja, ale i ślady użytkowania obu kodeksów - pelplińskiego i toruńskiego - noszą zbliżony charakter. W obu występują zapisy melodyczne na kartach ochronnych, uzupełnienia wersetów nadpisane w tekście, oznaczenia wspomagające użytkowanie. Można nawet przypuszczać, że niektóre nowożytne dopiski wyszły spod tej samej ręki, jakby obu ksiąg używano łącznie ${ }^{44}$. Graduał toruński zawiera wyłącznie część de tempore, ordinarium i kilka hymnów. Graduał pelpliński L2, niestety silnie wybrakowany, zawierał pierwotnie proprium de sanctis, bez oryginalnej foliacji, która już w rękopisie z MDT się urywa. Teza o wzajemnej przynależności obu ksiąg jako dwóch części proprium wydaje się kusząca. Oprócz Kyriale, żadna partia kodeksu MDT-K-o03 nie powtarza się w L2, a wśród pięćdziesięciu dwóch sekwencji L2 żadna nie powiela tych z graduału toruńskiego.

43 K. Radzka, op. cit., s. 94.

44 Uderzające podobieństwo, sugerujące tożsamość ręki pisarza, zdradzają przynajmniej dwa przypadki dopisków: Credo na recto karty ochronnej w egzemplarzu toruńskim i na karcie dodanej 134r w egzemplarzu pelplińskim, oraz dopisane zapisy słowno-muzyczne hymnu Lauda Sion na I7Iv w graduale toruńskim i wersu allelujatycznego na k. $58 \mathrm{r}$ w L2. 
Podsumowując, można postawić ostrożny, ale wiarygodny wniosek o istnieniu dwóch komplementarnych względem siebie części graduału z terenów państwa zakonnego, zawierających liturgię krzyżacką (?), które powstały jednocześnie i były razem używane - $\mathrm{i}$ to przez długi okres czasu. Kwestia ich związku z katedrą w Chełmży wymaga dalszych badań porównawczych, na tym etapie przede wszystkim muzykologicznych oraz analiz pod kątem uzusu i kapitulnych zwyczajów liturgicznych. $\mathrm{Na}$ ewentualne wykonawstwo omawianego tu graduału ze zbiorów toruńskich oraz siostrzanego L2 z Pelplina w skryptorium chełmżyńskim wskazywać może jednak porównanie ich $\mathrm{z}$ dwoma woluminami antyfonarza, przechowywanego $\mathrm{w}$ zbiorach Biblioteki Diecezjalnej w Pelplinie pod sygnaturami L5 i L645, którego uzus w ecclesiae culmensis jest poświadczony kolofonem: antyfonarz ten został spisany w I4I9 r. przez Jana z Jezioran na zlecenie dziekana kapituły w Chełmży, Jana Kopcia ${ }^{46}$. Dekoracja tych woluminów jest łączona z wpływami miniatorstwa czeskiego; już na wstępie badań nad całą tą grupą ksiąg można postawić tezę, że dekoracje gwaszowe kodeksu z Torunia i z chełmżyńnkiego antyfonarza wyrosły z jednego wspólnego źródła. Poświadcza to zarówno ogólna stylistyka miniatur, jak i ich szczegóły - np. rozwiązanie detali inicjałowych, charakterystyka postaci, opracowanie kolorystyczne. $\mathrm{Na}$ tym etapie prac pytanie o wspólnotę ich wykonawstwa pozostawiamy otwarte, poprzestając na konstatacji, że dokonana tu identyfikacja ważnego, ale mało znanego dzieła rękopiśmiennego, przechowywanego w zbiorach toruńskich, ma duży potencjał i w ujęciu porównawczym może prowadzić do wyłonienia konkretnego skryptorium, czynnego w pierwszej połowie XV w. przy katedrze w Chełmży.

45 I. Błaszczyk, „Iluminacje średniowiecznych rękopisów”, op. cit., s. II9 (bez wnikliwego rozpoznania); A. Karłowska-Kamzowa, op. cit., s. 208; Katarzyna Kluczwajd, „Antyfonarz”, w: Ars sacra, op. cit., nr 50, s. 54-55; Iwona Błaszczyk, „Antiphonarium de tempore et de sanctis”, w: Malarstwo gotyckie, op. cit., s. 3II-3I2.

46 Kolofon w L6, k. 285: „Anno domini. Millesimo. $\mathrm{C}^{\circ} \mathrm{CC}^{\circ} \mathrm{C}^{\circ}$ decimo nono. Com/pletus est liber iste. Estivalis $\mathrm{p}[\mathrm{er}] \mathrm{me}$ Iohanne[m] Cosi de Seburg. In vigilia visitationis s[an]ct[e] marie. Quem comp[ar]avit venerabil[is] / vir. frat[er] Iohan[n]es Copetz decanus eccl[es]i[a]e Colmen[sis]. In ho[no]re s[an]c[t]e $\mathrm{t}[\mathrm{ri}]$ nitatis [et] gloriose virginis marie. [et] o[mn]ium $s[\mathrm{an}] \mathrm{c}[\mathrm{t}]$ orum". 


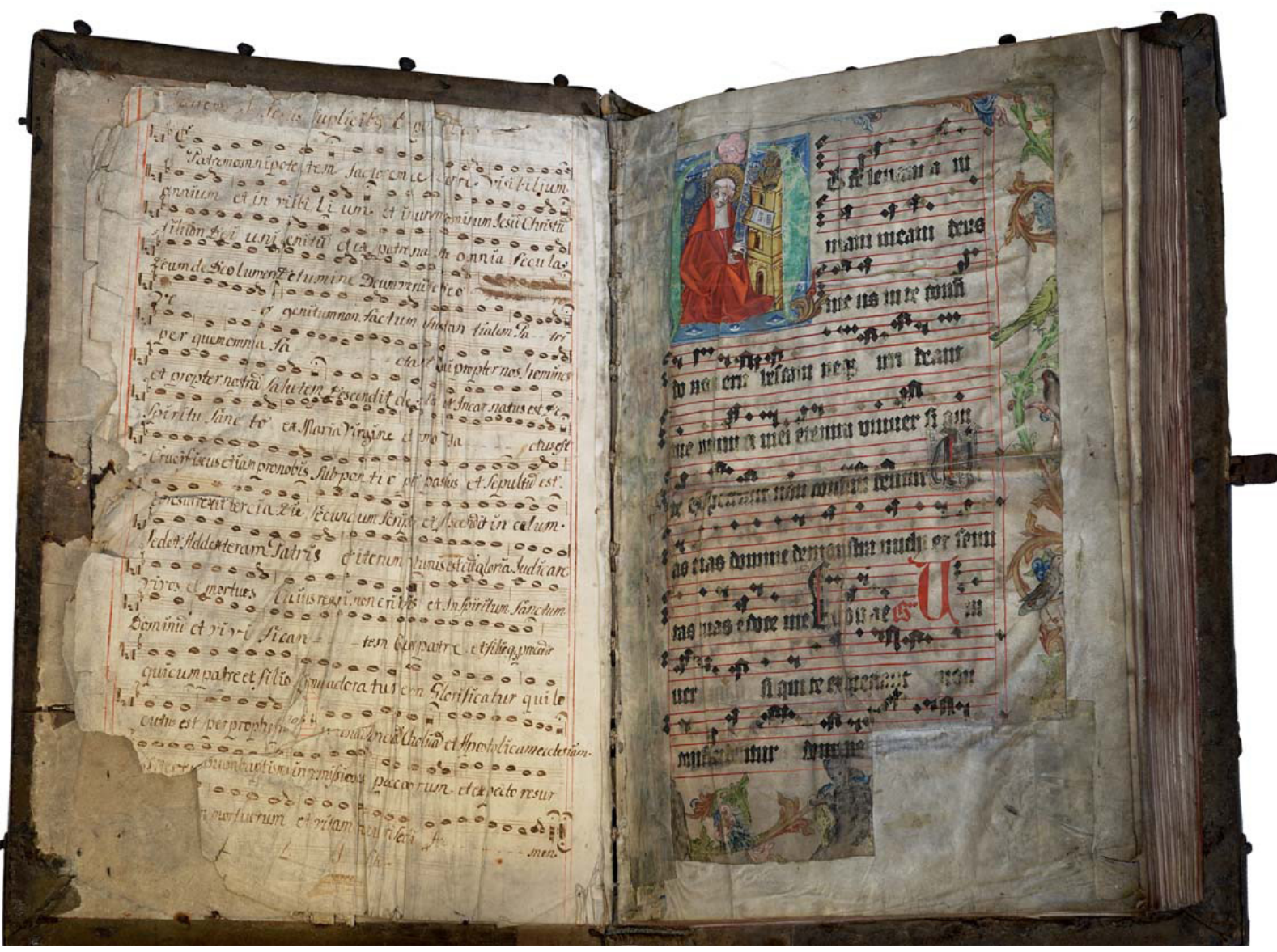

Il. I. Graduale de tempore, Toruń, Muzeum Diecezjalne, nr inw. MDT-K-oo3, kodeks otwarty na k. Ir. Fot. Juliusz Raczkowski. 


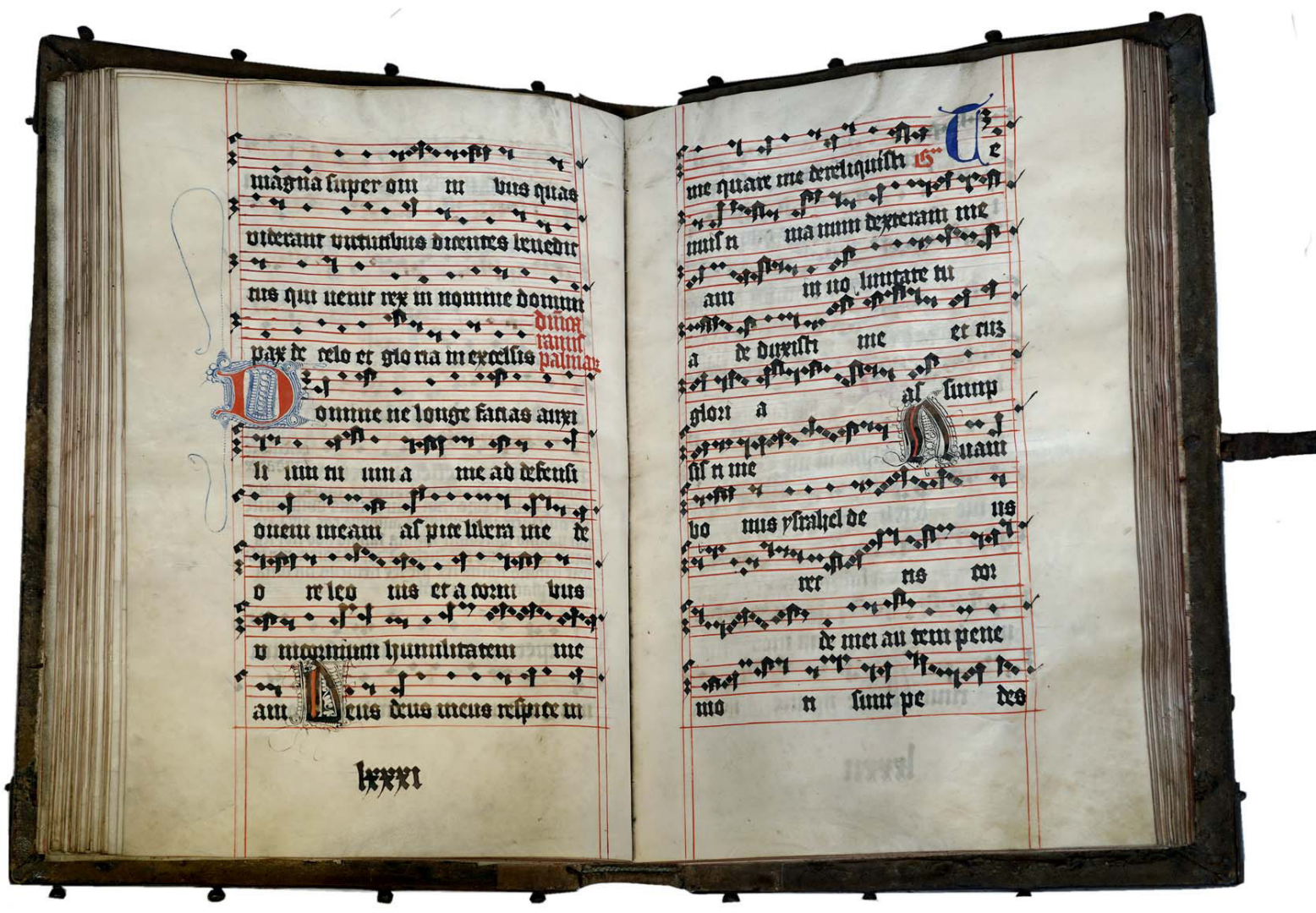

Il. 2. Graduale de tempore, Toruń, Muzeum Diecezjalne, nr inw. MDT-K-oo3, kodeks otwarty na k. 8Iv-82r. Fot. Juliusz Raczkowski. 


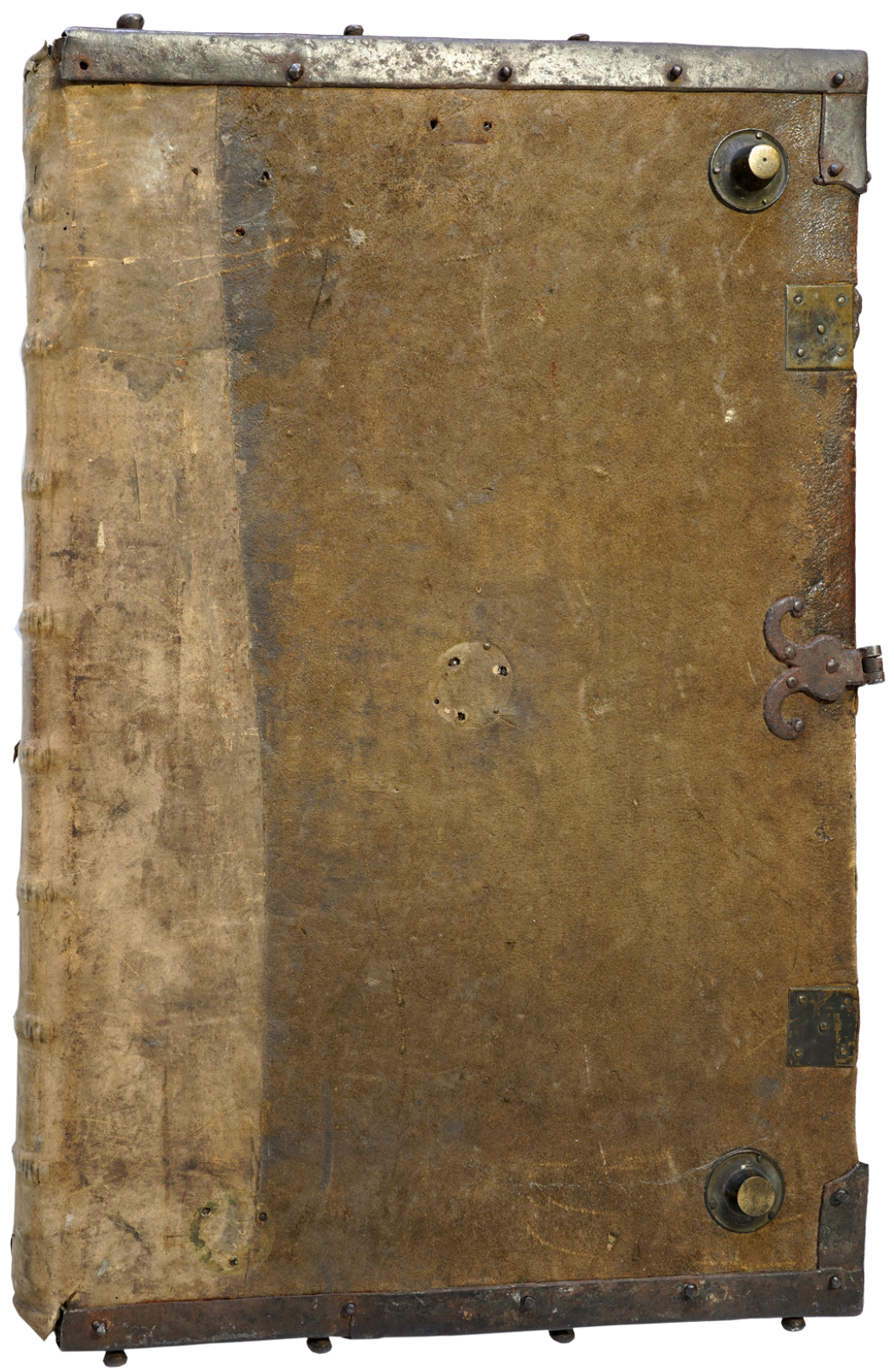

Il. 3. Graduale de tempore, Toruń, Muzeum Diecezjalne, nr inw. MDT-K-oo3, przednia okładzina oprawy. Fot. Juliusz Raczkowski. 


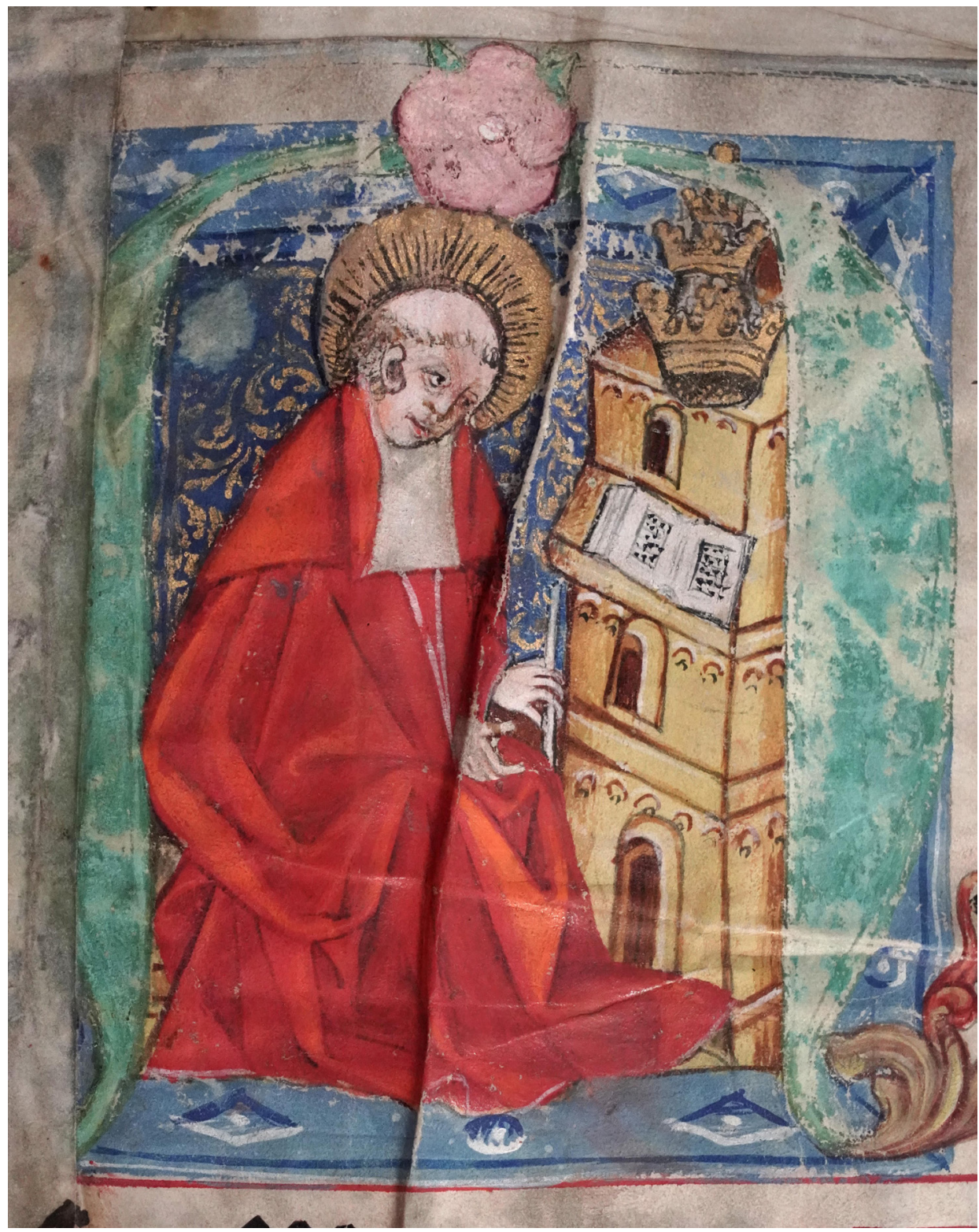

Il. 4. Graduale de tempore, Toruń, Muzeum Diecezjalne, nr inw. MDT-K-oo3, k. Ir - inicjał A(d) z wizerunkiem św. Grzegorza. Fot. Juliusz Raczkowski. 


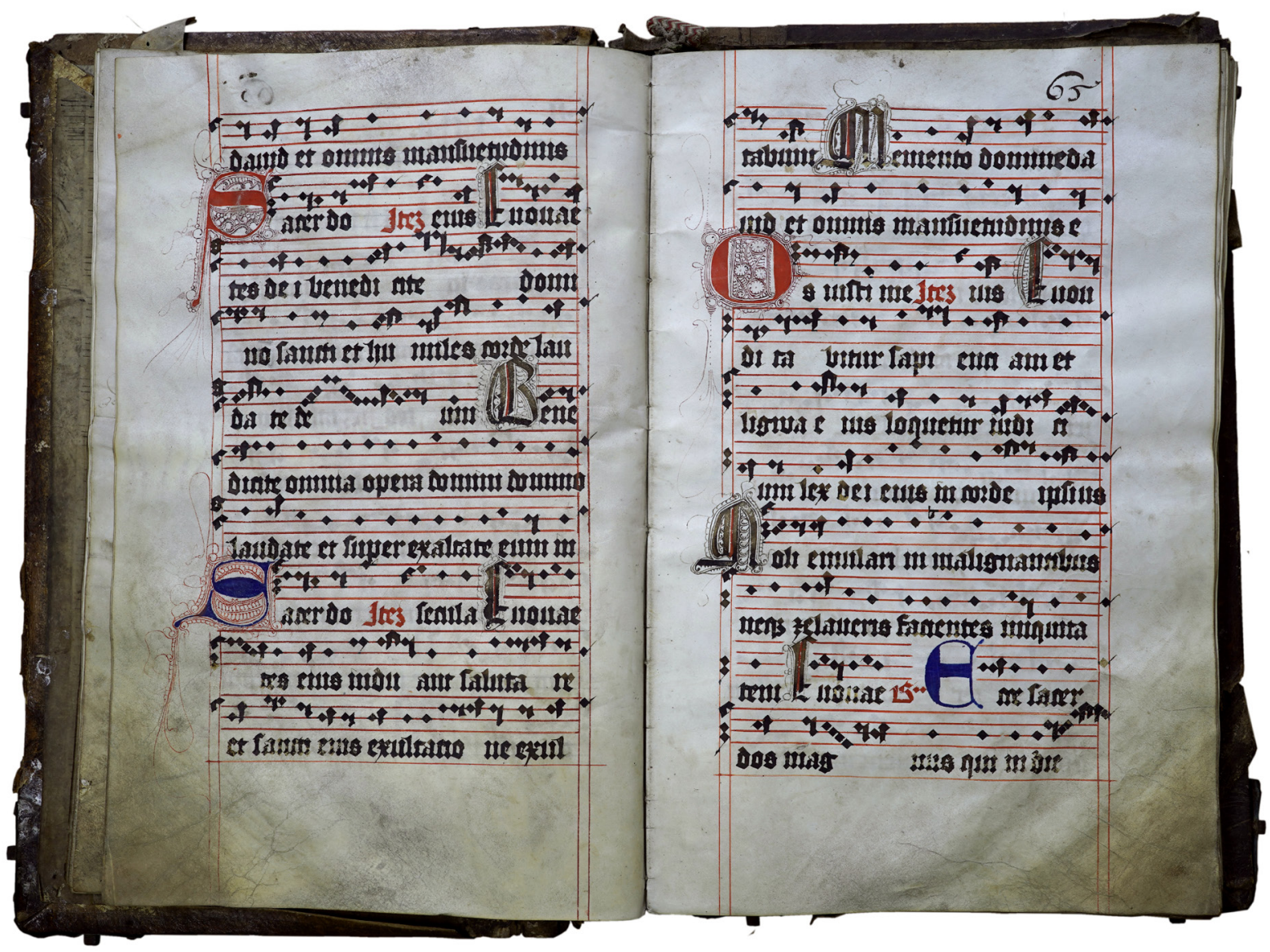

Il. 5. Graduale de sanctis, Pelplin, Biblioteka Diecezjalna, sygn. L2, kodeks otwarty na k. I2v-I3r (wg współczesnej foliacji). Fot. Juliusz Raczkowski. 


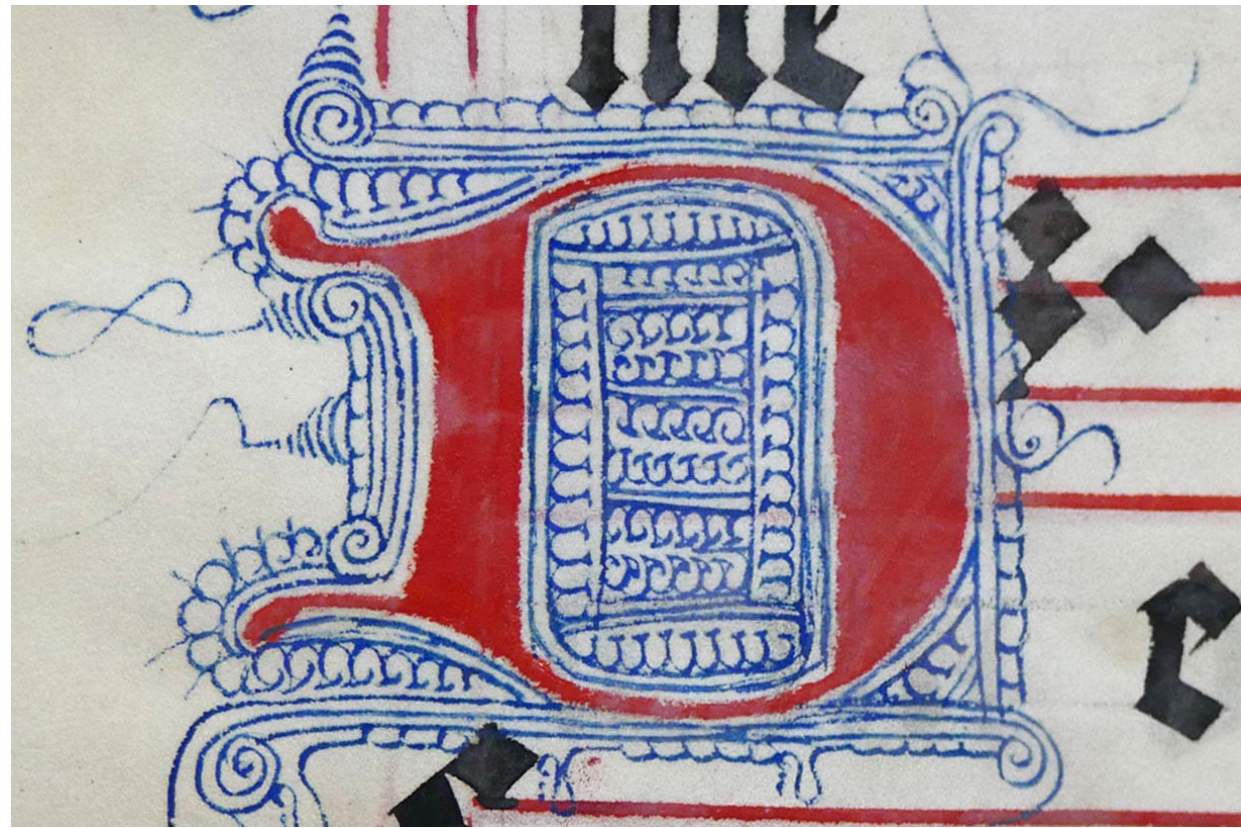

Il. 6. Graduale de tempore, Toruń, Muzeum Diecezjalne, nr inw. MDT-K-oo3, k. 4IV - inicjał D(e). Fot. Monika Jakubek-Raczkowska.

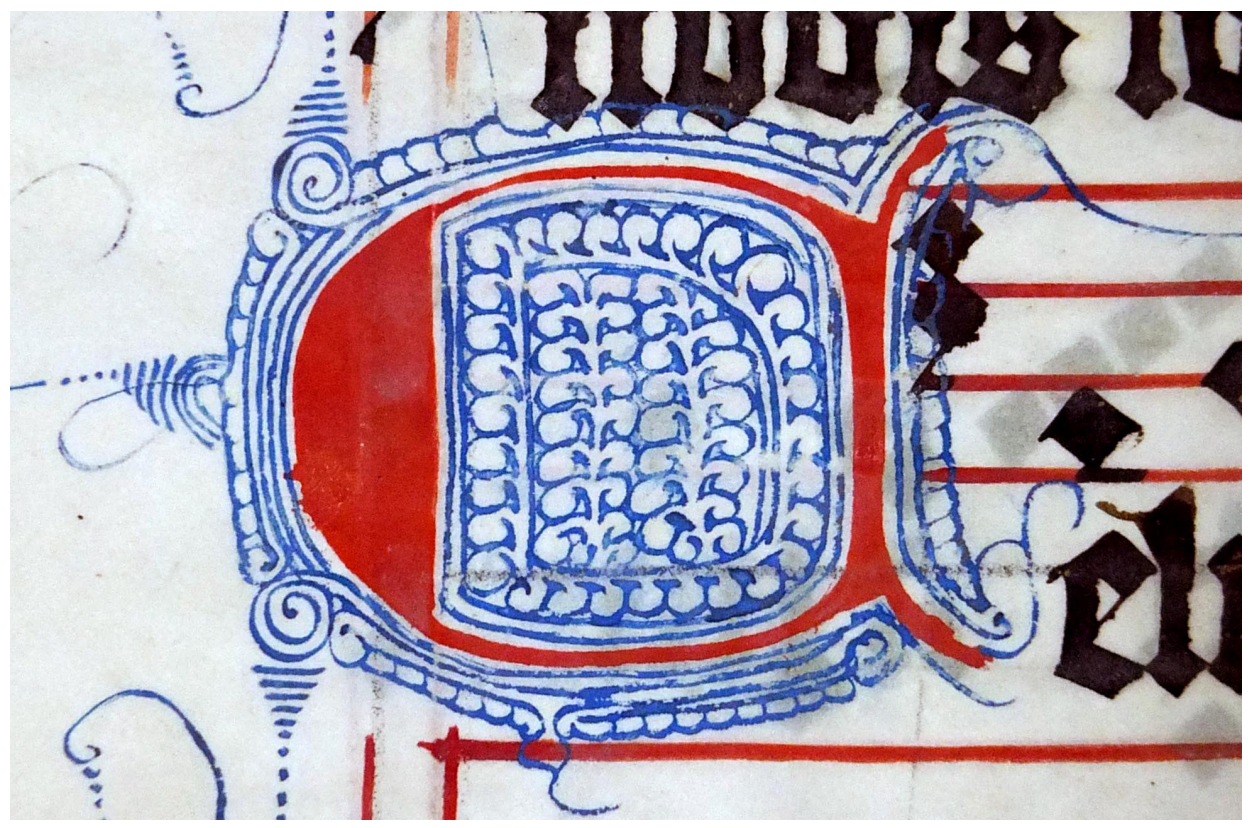

Il. 7. Graduale de tempore, Pelplin, Biblioteka Diecezjalna, sygn. L2, k. 7ov (wg współczesnej foliacji) inicjał C(eli). Fot. Mateusz F. Marszałkowski. 
AN UNRESEARCHED GRADUAL FROM ST JOHNS' CHURCH IN TORUŃ - A CONTRIBUTION TO THE STUDY OF MUSIC SOURCES IN THE CHEŁMNO DIOCESE IN THE MIDDLE AGES

This article presents preliminary results of codicological, historical and technological research into a medieval liturgical manuscript from the collection of the Diocesan Museum in Toruń (inv. no. MDT-K-003), carried out thanks to grant no. 0122/NPRH6/H11/85/2018, 'An Inventory of Toruńs Art', part 1, 'Sacred Art Heritage, Old Town Complex'. In the scant subject literature, this codex is identified as an antiphonary compiled for the parish church of SS John the Baptist and John the Evangelist in Torun (in the archive of which it remained until recently) and dated to the turn of the sixteenth century. In the present article, this book is identified as a Graduale de tempore used by the Teutonic Knights. The authors analyse the contents of the codex, discuss codicological issues related to its material structure and use, present a study of its decoration and draw new conclusions concerning its provenance. The book demonstrates very close analogies, with respect to both its original structure and the character of the later entries, to an incomplete Graduale de sanctis held in the Diocesan Museum in Pelplin (shelf mark L2). Both these manuscripts probably originated in the environment of Chełmża (Kulmsee) Cathedral Chapter (as is confirmed by comparative analysis with the decoration in the Pelplin Antiphonary L5-L6, compiled in 1419 at the request of Iohannes Copetz, dean of the chapter, in Chełmża (Kulmsee)). The two volumes can probably be dated to the second quarter of the fifteenth century. Our reinterpretation of an important but little-known handwritten source from the Torun collection shows considerable potential. Comparative studies may lead to the identification of a scriptorium operating in the first half of the fifteenth century at Chełmża (Kulmsee) Cathedral.

Translated by Tomasz Zymer

Słowa kluczowe / keywords: państwo zakonu krzyżackiego w Prusach / the state of the Teutonic Order in Prussia, liturgiczne księgi muzyczne / liturgical music books, graduał / gradual, kodeksy iluminowane / illuminated manuscripts, diecezja chełmińska / diocese of Kulm

Dr hab. Monika Jakubek-Raczkowska, prof. UMK, historyk sztuki, związana z Wydziałem Sztuk Pięknych UMK w Toruniu. Prowadzi badania nad powiązaniami średniowiecznej sztuki i pobożności oraz nad rzeźbą gotycką i odlewnictwem, ze szczególnym uwzględnieniem sztuki regionu pokrzyżackiego na tle europejskim. Ważnym przedmiotem jej studiów jest spuścizna rękopiśmienna: m.in. jest współautorką katalogu kodeksów średniowiecznych Biblioteki Uniwersyteckiej w Toruniu oraz monografii pelplińskiego graduału Li3.

mracz@umk.pl

Dr hab. Juliusz Raczkowski, prof. UMK, jest historykiem sztuki średniowiecznej i zabytkoznawca, zawodowo związany z Wydziałem Sztuk Pięknych UMK w Toruniu. Zainteresowanie badawcze koncentruje na sztuce państwa zakonnego w Prusach, ze szczególnym uwzględnieniem średniowiecznej architektury i wystroju oraz rzeźby snycerskiej i malarstwa tablicowego, przede wszystkim w kontekście problemów zabytkoznawczych i konserwatorskich, rozpatrywanych także od strony techniki i technologii. Jest koordynatorem projektu badawczego NPRH „Inwentarz Sztuki Torunia”. jracz@umk.pl 
